\title{
The oxidation of 2-(2-methoxyethoxy)-ethanol and 2-(2-ethoxyethoxy)-ethanol by dihydroxydiperiodato nickelate(IV): A kinetic and mechanistic study
}

\author{
Jinhuan Shan * and Ziwei Zhang \\ College of Chemistry and Environmental Science, Hebei University, Baoding 071002, China \\ ${ }^{*}$ Corresponding author at: College of Chemistry and Environmental Science, Hebei University, Baoding 071002, China. \\ Tel.: +86.0312.5971129. Fax: +86.0312.5079386. E-mail address: hbushanjh@163.com (J. Shan).
}

\section{ARTICLE INFORMATION}

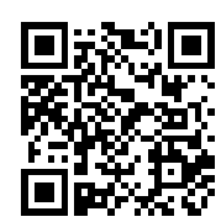

DOI: $10.5155 /$ eurjchem.5.2.237-240.981

Received: 22 November 2013

Received in revised form: 02 January 2014

Accepted: 04 January 2014

Online: 30 June 2014

\section{KEYWORDS}

\section{Kinetics}

Oxidation

Mechanism

2-(2-Ethoxyethoxy)-ethanol

2-(2-Methoxyethoxy)-ethanol

Dihydroxydiperiodatonickelate(IV)

\section{Introduction}

As researchers have acknowledged the existance of oxidation state of transition metals, and successfully prepared and isolated in the purified sample, with the help of a variety of analytical methods to infer the true structure of these complexes and analysis mode. In order to provide more accurate theoretical basis for analytical method, the study of the oxidation state of transition metals quickly become a hot topic. A large number of studies have showed that: transition metals in a higher oxidation state generally can be stabilized by chelation with suitable polydentate ligands. Metal chelates, such as ditelluratocuprate (III) [1-3] diperiodatocuprate (III) [4], diperiodatoargentate (III) [5,6], ditelluratoargentate (III) $[7,8]$, diperiodatonickelate (IV) $[9,10]$ are good oxidants in a medium with an appropriate $\mathrm{pH}$. Ni(IV) complexes have been employed as oxidizing agents for the investigation of some organic compounds. Currently, using diperiodatonickelate (IV) to oxidation amino acid [11,12], drugs [13] and catalytic oxidation has become a research hotspot. In addition, a new chemiluminescence (CL) [14] reaction that occurs between luminol and di-periodatonickelate in alkaline medium had been reported.

In the present manuscript, the mechanism of oxidation of 2(2-methoxyethoxy)-ethanol and 2-(2-ethoxyethoxy)-ethanol by diperiodatonickelate(IV) is reported. Both 2-(2-methoxy ethoxy)-ethanol (MEE) and 2-(2-ethoxyethoxy)-ethanol (EEE) are colorless liquids and high boiling-point solvents which means they will have a wide application, such as non-polluting cleaning agents, extraction agents, diluent, medicine, additives and solvent, etc.

\section{Experimental}

\subsection{Materials}

All chemicals used were of A.R. grade and double distilled water was used throughout this work. Solutions of $\left[\mathrm{Ni}(\mathrm{OH})_{2}\left(\mathrm{H}_{2} \mathrm{IO}_{6}\right)_{2}\right]^{4-}$ DPN and reductants were always freshly prepared before use. The stock solution of DPN was prepared and standardized by the method report earlier [15]. The concentration of DPN was derived from its absorption at $\lambda=410 \mathrm{~nm} . \mathrm{KNO}_{3}$ and $\mathrm{KOH}$ were used to maintain ionic strength and alkalinity of the reaction, respectively. The concentration of reductants must be more 20 times than the concentration of DPN.

\subsection{Instrumentation}

The measurements of the kinetic were performed on a UVVis spectrophotometer (TU-1900, Beijing Puxi Inc., China), which had a cell-holder kept at a constant temperature 
$\left( \pm 0.1^{\circ} \mathrm{C}\right)$ by circulating water from a thermostat (DC-2010, Baoding, China).

\subsection{Kinetics measurements}

All kinetic measurements were carried out under pseudofirst-order conditions. Solution $(2 \mathrm{~mL})$ containing required concentration of $\mathrm{Ni}(\mathrm{IV}), \mathrm{OH}^{-}, \mathrm{IO}_{4}^{-}$and ionic strength and reductant solution $(2 \mathrm{~mL})$ of requisite concentration were mixed at the desired temperature, and immediately transferred into a $1 \mathrm{~cm}$ thick rectangular quartz cell in a constant temperature cell-holder $\left( \pm 0.1^{\circ} \mathrm{C}\right.$ ) When the DPN colour (wine red) was completed fading marked the completion of the reaction.

\section{Results and discussion}

\subsection{Evaluation of pseudo-first order rate constants}

Under the conditions of [reductant $]_{0} \gg[\mathrm{DPN}]_{0}$, the plots of $\ln \left(A_{t}-A_{\infty}\right)$ vs time were straight lines, showing that the reaction was first order with respect to $\mathrm{Ni}(\mathrm{IV})$, where $\mathrm{At}_{\mathrm{t}}$ and $\mathrm{A}_{\infty}$ were the absorbance at time $t$ and at infinite time, respectively. The pseudo-first-order rate constants $k_{\text {obs }}$ were calculated by the method of least squares $(r \geq 0.996)$. Deviations in duplicate determinations were generally less than $\pm 5 \%$.

\subsection{Rate dependence on the [reductant]}

At fixed concentration $\mathrm{Ni}(\mathrm{IV}), \mathrm{OH}^{-}, \mathrm{IO}_{4}^{-}$, ionic strength $\mu$ and temperature, The order nap were found to be first in [MEE] and [EEE], and the $k_{\mathrm{obs}}$ value increased with the increasing [reductant]. Both the plot of $k_{o b s} v s$ [MEE] and the plot of $k_{\mathrm{obs}} v s$ [EEE] were straight lines, which through the origin at different temperature which the corresponding equation. $(r \geq 0.997)$ (Figure 1 and 2).

$$
k_{\text {obs }}=\mathrm{a} \times\left[\mathrm{R}^{\prime}\right]
$$

From the Equation (1) we can indicate that the reaction order dependence on reductant was first order and $\mathrm{R}^{\prime}$ represents (2-(2-methoxyethoxy)-ethanol (MEE) and 2-(2ethoxyethoxy)-ethanol (EEE).

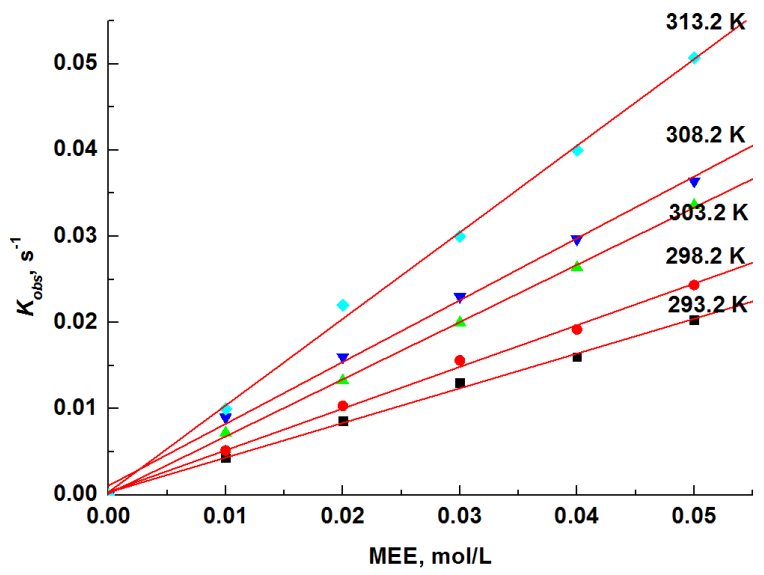

Figure 1. Plots of $k_{\mathrm{obs}} v s$. [MEE] at different temperatures, [DPN] $=5.91 \times 10^{-6}$ $\mathrm{mol} / \mathrm{L},\left[\mathrm{IO}_{4}^{-}\right]=1.00 \times 10^{-3} \mathrm{~mol} / \mathrm{L},[\mathrm{OH}-]=1.00 \times 10^{-2} \mathrm{~mol} / \mathrm{L}, \mu=3.10 \times 10^{-2}$ $\mathrm{mol} / \mathrm{L}$.

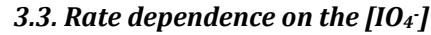

Under the condition of [reductant $]_{0}>>[\mathrm{DPN}]_{0}$, at constant [reductant], $\left[\mathrm{OH}^{-}\right]$, ionic strength and temperature, $k_{\mathrm{obs}}$ values decreased with the increase in concentration of $\mathrm{IO}_{4}^{-}$and the order with respect to $\left[\mathrm{IO}_{4}{ }^{-}\right]$was found to be fractional, which revealed that $\left[\mathrm{IO}_{4}^{-}\right]$was produced in equilibrium before the rate-determining step. The plots of $1 / k_{\mathrm{obs}} v s\left[\mathrm{IO}_{4}{ }^{-}\right]$were all straight lines without passing through the origin (Figure 3 and 4).

$\frac{1}{k_{o b s}}=b+c \times\left[\mathrm{IO}_{4}^{-}\right]$

The Equation (2) showing that there was a pre-equilibrium involving the process of disassociation $\mathrm{H}_{2} \mathrm{IO}_{6}{ }^{3-}$ from $\mathrm{Ni}(\mathrm{IV})$ complex.

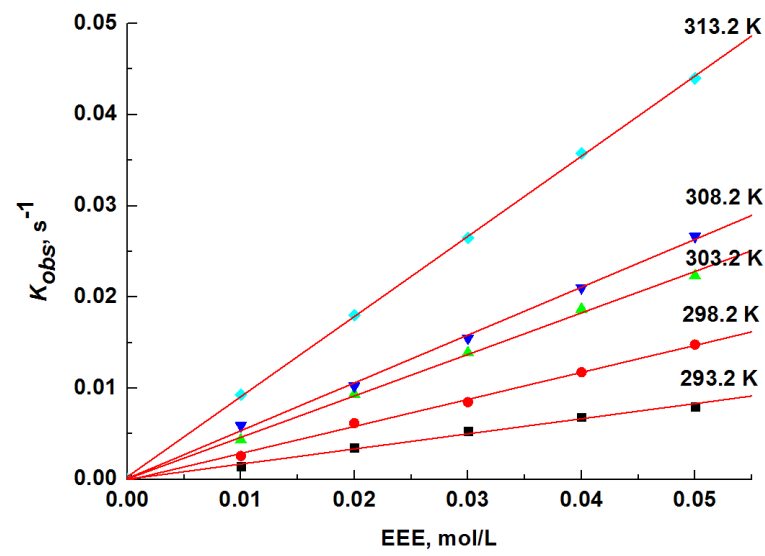

Figure 2. Plots of $k_{\mathrm{obs}} v s$. [EEE] at different temperatures, [DPN] $=5.91 \times 10^{-6}$ $\mathrm{mol} / \mathrm{L},\left[\mathrm{IO}_{4}^{-}\right]=1.00 \times 10^{-3} \mathrm{~mol} / \mathrm{L},\left[\mathrm{OH}^{-}\right]=1.00 \times 10^{-2} \mathrm{~mol} / \mathrm{L}, \mu=3.10 \times 10^{-2}$ $\mathrm{mol} / \mathrm{L}$.

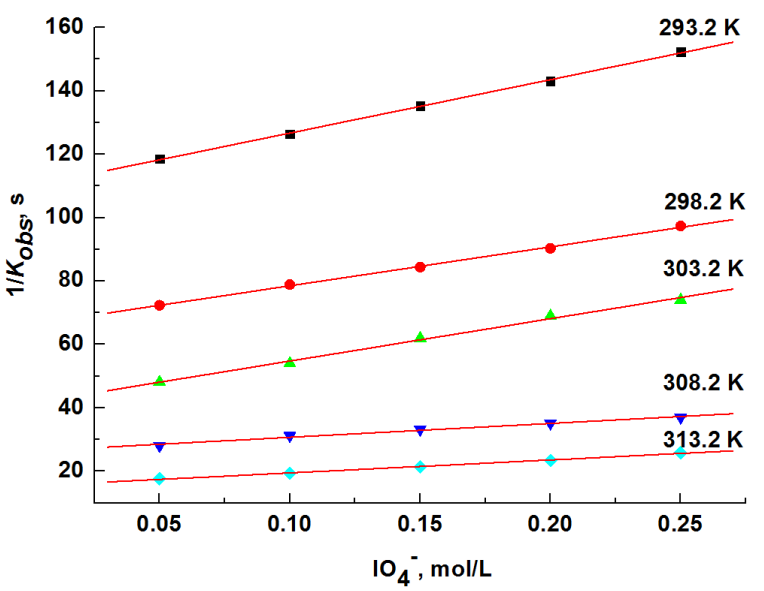

Figure 3. Plot of $1 / k_{\mathrm{obs}}$ vs $10^{2}\left[\mathrm{IO}_{4}^{-}\right]$at $303.2 \mathrm{~K},[\mathrm{DPN}]=5.91 \times 10^{-6} \mathrm{~mol} / \mathrm{L}$, $[\mathrm{MEE}]=3.00 \times 10^{-2} \mathrm{~mol} / \mathrm{L},[\mathrm{OH}-]=1.00 \times 10^{-2} \mathrm{~mol} / \mathrm{L}, \mu=3.10 \times 10^{-2} \mathrm{~mol} / \mathrm{L}(r \geq$ 0.996).

\subsection{Rate dependence on the [OH-]}

At fixed concentrations of $\mathrm{DPN}, \mathrm{IO}_{4}$, reductant, ionic strength $\mu$ and temperature $(303.2 \mathrm{~K})$, the value of $k_{\text {obs }}$ increased with increasing concentration of $\mathrm{OH}^{-}$. The order with respect to $\left[\mathrm{OH}^{-}\right]$was fractional and the plots of $1 / k_{\mathrm{obs}} v s$ $f\left(\left[\mathrm{OH}^{-}\right]\right) /\left[\mathrm{OH}^{-}\right]$were observed which the corresponding linear equation at different temperatures; 
Table 1. Effect of $\left[\mathrm{OH}^{-}\right],\left[\mathrm{IO}_{4}^{-}\right]$and $\mu$ on the reaction at $303.2 \mathrm{~K}$.

\begin{tabular}{|c|c|c|c|c|c|c|}
\hline $\begin{array}{l}10^{-6}[\mathrm{DPN}] \\
(\mathrm{mol} / \mathrm{L})\end{array}$ & $\begin{array}{l}\text { [reductant] } \\
\text { (mol/L) }\end{array}$ & $\begin{array}{l}\mu \times 10^{2} \\
(\mathrm{~mol} / \mathrm{L})\end{array}$ & $\begin{array}{l}10^{3}\left[\mathrm{IO}_{4}-\right] \\
(\mathrm{mol} / \mathrm{L})\end{array}$ & $\begin{array}{l}10^{3}[\mathrm{OH}-] \\
(\mathrm{mol} / \mathrm{L})\end{array}$ & $\begin{array}{l}\text { MEE } \\
10^{3} k_{\text {obs }}\left(\mathrm{s}^{-1}\right)\end{array}$ & $\begin{array}{l}\text { EEE } \\
10^{3} k_{\text {obs }}\left(s^{-1}\right)\end{array}$ \\
\hline 5.91 & 0.03 & 3.10 & 1.00 & 5.00 & 13.10 & 10.49 \\
\hline 5.91 & 0.03 & 3.10 & 1.00 & 10.00 & 19.97 & 14.09 \\
\hline 5.91 & 0.03 & 3.10 & 1.00 & 15.00 & 26.23 & 16.07 \\
\hline 5.91 & 0.03 & 3.10 & 1.00 & 20.00 & 31.05 & 17.76 \\
\hline 5.91 & 0.03 & 3.10 & 1.00 & 25.00 & 35.23 & 18.75 \\
\hline 5.91 & 0.03 & 3.10 & 0.50 & 10.00 & 20.77 & 14.53 \\
\hline 5.91 & 0.03 & 3.10 & 1.00 & 10.00 & 18.52 & 13.03 \\
\hline 5.91 & 0.03 & 3.10 & 1.50 & 10.00 & 16.13 & 12.08 \\
\hline 5.91 & 0.03 & 3.10 & 2.00 & 10.00 & 14.49 & 11.14 \\
\hline 5.91 & 0.03 & 3.10 & 2.50 & 10.00 & 13.51 & 10.42 \\
\hline 5.91 & 0.03 & 1.10 & 1.00 & 10.00 & 13.23 & 11.61 \\
\hline 5.91 & 0.03 & 2.10 & 1.00 & 10.00 & 14.12 & 12.53 \\
\hline 5.91 & 0.03 & 3.10 & 1.00 & 10.00 & 15.34 & 13.52 \\
\hline 5.91 & 0.03 & 4.10 & 1.00 & 10.00 & 17.12 & 14.71 \\
\hline 5.91 & 0.03 & 5.10 & 1.00 & 10.00 & 18.41 & 15.24 \\
\hline
\end{tabular}

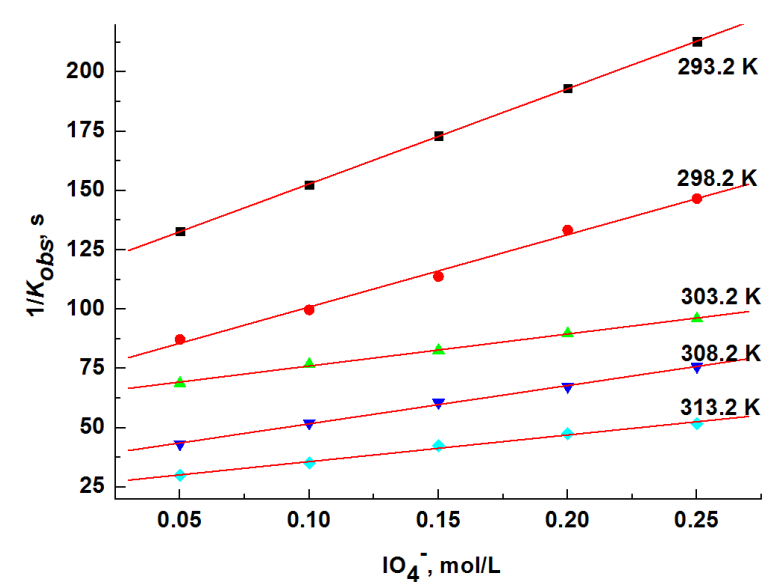

Figure 4. Plot of $1 / k_{\mathrm{obs}} v s 10^{2}\left[\mathrm{IO}_{4}^{-}\right]$at $303.2 \mathrm{~K}$, [DPN] $=5.91 \times 10^{-6} \mathrm{~mol} / \mathrm{L}$, $[\mathrm{EEE}]=3.00 \times 10^{-2} \mathrm{~mol} / \mathrm{L},\left[\mathrm{OH}^{-}\right]=1.00 \times 10^{-2} \mathrm{~mol} / \mathrm{L}, \mu=3.10 \times 10^{-2} \mathrm{~mol} / \mathrm{L}(r \geq$ 0.998).

$\frac{1}{k_{o b s}}=d+e \times f\left(\left[\mathrm{OH}^{-}\right]\right) /\left[\mathrm{OH}^{-}\right]$

\subsection{Rate dependence on ionic strength $\mu$}

The effect of ionic strength on the reaction was studied in the range of $1.10 \times 10^{-2}$ to $5.10 \times 10^{-2} \mathrm{~mol} / \mathrm{L}$ at constant [DPN], [reductant], [OH-], [ $\left.\mathrm{IO}_{4}^{-}\right]$and temperature. The experimental results indicated that the rate constant $k_{\mathrm{obs}}$ increased with increased in ionic strength $\mu$ (Table 1), which showed that there was a positive salt effect that consistent with the common regulation of the kinetics [16].

\subsection{Free radical detection}

To study the possible presence of a free radical during the reaction, a known amount of acrylamide was added under the protection of nitrogen atmosphere. There was no polymeric suspensions appeared which indicated that no free radical intermediates produced in the oxidation by DPN.

\subsection{Reaction mechanism}

In alkaline solution, Equilibrium (4-6) was observed and the corresponding equilibrium constants at $298.2 \mathrm{~K}$ were determined by Aveston [17].

$$
\begin{aligned}
& 2 \mathrm{IO}_{4^{-}}+2 \mathrm{OH} \mathrm{H}^{-} \leftrightharpoons \mathrm{H}_{2} \mathrm{I}_{2} \mathrm{O}_{10^{4-}} \quad \log \beta_{1}=15.05 \\
& \mathrm{IO}_{4}^{-}+\mathrm{OH}^{-}+\mathrm{H}_{2} \mathrm{O} \leftrightharpoons \mathrm{H}_{3} \mathrm{IO}_{6}{ }^{2-} \quad \log \beta_{2}=6.21 \\
& \mathrm{IO}_{4^{-}}+2 \mathrm{OH}^{-} \leftrightharpoons \mathrm{H}_{2} \mathrm{IO}_{6}{ }^{3-} \quad \log \beta_{3}=8.67
\end{aligned}
$$

The distribution of all periodate species in alkaline solution can be calculated from the equilibriums (4-6). The amount of dimer $\mathrm{H}_{2} \mathrm{I}_{2} \mathrm{O}_{10^{4-}}$ and $\mathrm{IO}_{4}^{-}$species can be neglected, the main species of periodate are $\mathrm{H}_{3} \mathrm{IO}_{6}{ }^{2-}$ and $\mathrm{H}_{2} \mathrm{IO}_{6}{ }^{3-}$, which was consistent with the result calculated from Crouthamel's date by Murthy $[18,19]$. Based on such distribution, the formula of $\mathrm{Ni}(\mathrm{IV})$ periodate complex is represented by the less protonated ionic species $\left[\mathrm{Ni}(\mathrm{OH})_{2}\left(\mathrm{H}_{2} \mathrm{IO}_{6}\right)_{2}\right]^{4-}$. We preferred to use $\left[\mathrm{Ni}(\mathrm{OH})_{2}\left(\mathrm{H}_{2} \mathrm{IO}_{6}\right)_{2}\right]^{4-}$ to represent DPN because it is close to the formula suggested by Mukherjee [16] and will obtain support from kinetic studies.

According to the above experimental facts, the plausible mechanism of oxidation was proposed as follows:

$\underset{\text { DPN }}{\left[\mathrm{Ni}(\mathrm{OH})_{2}\left(\mathrm{H}_{2} \mathrm{IO}_{6}\right)_{2}\right]^{4-}+\mathrm{OH}-\underset{\mathrm{K}}{\rightleftharpoons}\left[\mathrm{Ni}(\mathrm{OH})_{2}\left(\mathrm{HIO}_{6}\right)\right]^{2-}+\mathrm{H}_{2} \mathrm{IO}_{6}^{3-}+\mathrm{H}_{2} \mathrm{O}}$

$\left[\mathrm{Ni}(\mathrm{OH})_{2}\left(\mathrm{HIO}_{6}\right)\right]^{2-}+\mathrm{R}^{\prime} \stackrel{k}{\longrightarrow}$ Adduct MPN

Adduct $\stackrel{\text { Fast }}{\longrightarrow} \mathrm{Ni}(\mathrm{IV})+$ Product

Reaction (8) is the rate-determining step.

$-\frac{\mathrm{d}[\mathrm{Ni}(\mathrm{IV})]_{\mathrm{T}}}{\mathrm{dt}}=\frac{k \mathrm{~K}\left[\mathrm{OH}^{-}\right]\left[\mathrm{R}^{\prime}\right]}{\left[\mathrm{H}_{2} \mathrm{IO}_{6}{ }^{3-}\right]+\mathrm{K}\left[\mathrm{OH}^{-}\right]} \times[\mathrm{Ni}(\mathrm{IV})]_{\mathrm{T}}=k_{\mathrm{obs}}[\mathrm{Ni}(\mathrm{IV})]_{\mathrm{T}}$

$k_{\mathrm{obs}}=\frac{k \mathrm{~K}\left[\mathrm{OH}^{-}\right]}{\left[\mathrm{H}_{2} \mathrm{IO}_{6}{ }^{3-}\right]+\mathrm{K}\left[\mathrm{OH}^{-}\right]} \times\left[\mathrm{R}^{\prime}\right]$

Here:

$[\mathrm{Ni}(\mathrm{IV})]_{\mathrm{T}}=[\mathrm{DPN}]_{\mathrm{e}}+[\mathrm{MPN}]_{\mathrm{e}}=[\mathrm{MPN}]_{\mathrm{e}}\left(\frac{\left[\mathrm{H}_{2} \mathrm{IO}_{6}{ }^{3-}\right]+k\left[\mathrm{OH}^{-}\right]}{k\left[\mathrm{OH}^{-}\right]}\right)$

Subscripts $\mathrm{T}$ and e stand for total concentration and concentration at equilibrium respectively. 
Table 2. Rate constants (k) and the activation parameters for the rate-determining step *

\begin{tabular}{|c|c|c|c|c|c|c|}
\hline \multirow{3}{*}{$\frac{T(\mathbf{T})}{10^{2} k\left(\mathrm{~s}^{-1}\right)}$} & & 293.2 & 298.2 & 303.2 & 308.2 & 313.2 \\
\hline & MEE & 33.37 & 42.72 & 62.66 & 81.30 & 112.84 \\
\hline & EEE & 34.22 & 44.66 & 64.60 & 92.34 & 143.06 \\
\hline \multirow{2}{*}{$\begin{array}{l}\text { Thermodynamic activation } \\
\text { Parameters (298.2 K) }\end{array}$} & MEE & \multicolumn{5}{|c|}{$E_{\mathrm{a}}=32.42 \mathrm{~kJ} / \mathrm{mol}, \Delta H^{\neq}=29.94 \mathrm{~kJ} / \mathrm{mol}, \Delta S^{\neq}=-234.09 \mathrm{~J} / \mathrm{K} \cdot \mathrm{mol}$} \\
\hline & EEE & \multicolumn{5}{|c|}{$E_{\mathrm{a}}=56.80 \mathrm{~kJ} / \mathrm{mol}, \Delta H^{\neq}=54.32 \mathrm{~kJ} / \mathrm{mol}, \Delta S^{\neq}=-228.96 \mathrm{~J} / \mathrm{K} \cdot \mathrm{mol}$} \\
\hline
\end{tabular}

Neglecting the concentration of ligand dissociated from $\mathrm{Ni}(\mathrm{IV})$ and the species of periodate other than $\mathrm{H}_{2} \mathrm{IO}_{6}{ }^{3-}$ and $\mathrm{H}_{3} \mathrm{IO}_{6}{ }^{2-}$, equations (13) and (14) can be obtained from the Equations (5) and (6):

$$
\begin{aligned}
& {\left[\mathrm{H}_{2} \mathrm{IO}_{6}{ }^{3-}\right]=\frac{\beta_{3}\left[\mathrm{OH}^{-}\right]}{\beta_{2}+\beta_{3}\left[\mathrm{OH}^{-}\right]} \times\left[\mathrm{IO}_{4}^{-}\right]_{\mathrm{ex}}=f\left(\left[\mathrm{OH}^{-}\right]\right)\left[\mathrm{IO}_{4}^{-}\right]_{\mathrm{ex}}} \\
& {\left[\mathrm{H}_{3} \mathrm{IO}_{6}{ }^{2-}\right]=\frac{\beta_{2}}{\beta_{2}+\beta_{3}\left[\mathrm{OH}^{-}\right]} \times\left[\mathrm{IO}_{4}^{-}\right]_{\mathrm{ex}}=\varphi\left(\left[\mathrm{OH}^{-}\right]\right)\left[\mathrm{IO}_{4}^{-}\right]_{\mathrm{ex}}}
\end{aligned}
$$

Here $\left[\mathrm{IO}_{4}^{-}\right]_{\text {ex }}$ represents the original overall entering periodate and equals approximately to the sum of $\left[\mathrm{H}_{2} \mathrm{IO}_{6}{ }^{3-}\right]$ and $\left[\mathrm{H}_{3} \mathrm{IO}_{6}^{2-}\right]$.

Substituting equation (13) into (11), we can get the expression of pseudo-first order rate constants as:

$$
\begin{aligned}
& \frac{1}{k_{\mathrm{obs}}}=\frac{1}{k\left[\mathrm{R}^{\prime}\right]}+\frac{\left[\mathrm{IO}_{4}^{-}\right]_{\mathrm{ex}}}{k \mathrm{~K}\left[\mathrm{R}^{\prime}\right]} \times \frac{f\left(\left[\mathrm{OH}^{-}\right]\right)}{\left[\mathrm{OH}^{-}\right]} \\
& \frac{1}{k_{\mathrm{obs}}}=\frac{1}{k\left[\mathrm{R}^{\prime}\right]}+\frac{f\left(\left[\mathrm{OH}^{-}\right]\right)}{k \mathrm{~K}\left[\mathrm{R}^{\prime}\right]\left[\mathrm{OH}^{-}\right]} \times\left[\mathrm{IO}_{4}^{-}\right]_{\mathrm{ex}}
\end{aligned}
$$

The equation (11), (15), and (16) are consistent with equation (1), (2), and (3), respectively, which mentioned formerly. This is consistent with the experiments result. From the intercept of equation (16), we can obtain the rate constants of the rate-determining step at different temperatures, and activation energy and the thermodynamic parameters are evaluated by the method given earlier [20].

If the formula of DPN was $\left[\mathrm{Ni}(\mathrm{OH})_{2}\left(\mathrm{H}_{3} \mathrm{IO}_{6}\right)_{2}\right]^{2-}$, equation (17) would be obtained instead of equation (14).

$\frac{1}{k_{\mathrm{obs}}}=\frac{1}{k\left[\mathrm{R}^{\prime}\right]}+\frac{\left[\mathrm{IO}_{4}^{-}\right]}{k \mathrm{~K}\left[\mathrm{R}^{\prime}\right]} \times \frac{\varphi\left(\left[\mathrm{OH}^{-}\right]\right)}{\left[\mathrm{OH}^{-}\right]}$

The plot of $1 / k_{\text {obs }}$ vs. $\varphi\left(\left[\mathrm{OH}^{-}\right]\right) /\left[\mathrm{OH}^{-}\right]$should also be linear, but the linearity was not straight (Table 1), which substantially denies equation (13). Therefore, it seems advisable to represent DPN by $\left[\mathrm{Ni}(\mathrm{OH})_{2}\left(\mathrm{H}_{2} \mathrm{IO}_{6}\right)_{2}\right]^{4-}$, which is consistent with the experimental result.

Meanwhile, the pots of $1 / k_{\text {obs }}$ vs $\left[\mathrm{IO}_{4}^{-}\right]$were linear at different temperatures. From their slopes, the rate-determining step constants $\mathrm{k}$ was evaluated. The activation parameters data of reductant obtained is presented in Table 2.

\section{Conclusion}

In this study, we noted that the rate constants $k$ of the ratedetermining step and the activation parameters for 2-(2methoxyethoxy)-ethanol and 2-(2-ethoxyethoxy)-ethanol are contiguous. The reaction rate 2-(2-methoxyethoxy)-ethanol is a little quicker than that of 2-(2-ethoxyethoxy)-ethanol. The reason is that comparing 2-(2-methoxyethoxy)-ethanol, 2-(2ethoxyethoxy)-ethanol is larger and has larger spatial hindrance. The latter is more stable than the former.

\section{References}

[1]. Shan, J. H.; Li, Y.; Huo, S. H.; Yin, C. H. J. Chem. 2013, 2013, Article ID 627324.

[2]. Shan, J. H.; Li, Y. Eur. J. Chem. 2013, 4(3), 203-206

[3]. Shan, J. H.; Liu, Y. P.; Zhang, J. Y. Chinese J. Chem. 2011, 29(4), 639-642.

[4]. Shan, J. H.; Liu, Y. P.; Shen, H. X.; Zhang, J. Y.; Yang, Y. F. Int. J. Chem. 2011, 3(2), 111-116.

[5]. Naik, K. M.; Nandibewoor, S. T. Oxid. Commun. 2012, 35, 545-559.

[6]. Shan, J. H.; Wang, X. Q.; Zhao, N. Chinese J. Chem. 2010, 28(7), 10811084.

[7]. Ragunatharaddi, R. H.; Nagaraj, P. S.; Sharanappa, T. N. J. Phys. Org. Chem. 2009, 22(3), 234-240.

[8]. Jayant, I. G.; Sanjeevaraddi, R. S.; Sharanappa, T. N. Catal. Sci. Technol. 2012, 2, 2549-2557.

[9]. Shan, J. H.; Liu, H. M.; Huo, S. Y.; Fan, Y.; Shen, S. G. Trans. Met. Chem 2006, 31, 999-1002.

[10]. Shan, J. H.; Shen, H. X.; Song, C. Y.; Wang, H. Y.; Wang, X. Q. Chem. J. Inter. 2009, 11(3),10

[11]. Shan, J. H.; Wei, H. Y.; Wang, L.; Liu, B. S.; Shen, S. G.; Sun, H. W. Indian J. Chem. 2001, 40(A), 865-869.

[12]. Shan, J. H.; Shen, H. X.; Wang, H. Y.; Wang, X. Q. Oxid. Commun. 2012, 35(3), 583-390.

[13]. Yang, C. Y.; Zhang, Z. J.; Wang, J. L. Microchim. Acta 2009, 167, 91-96.

[14]. Chandraiah, U.; Murthy, C. P.; Sushama, Indian J. Chem. 1989, 28(A), 162-164.

[15]. Murthy, C. P.; Sethuram, B.; Rao, T. N. Z. Phys. Chem. (Leipzig) 1986, 267, 1212-1218

[16]. Mahesh, R. T.; Pol, P. D.; Nandibewoor, S. T. Monatsh. Chem. 2003, 134, 1341-1352.

[17]. Aveston, J. J. Chem. Soc. 1969, A, 273-275.

[18]. Crouthamel, C. E.; Meek, H. V.; Martin, D. S. J. Am. Chem. Soc. 1949, 71, 3031-3035

[19]. Crouthamel, C. E.; Hayes, A. M.; Martin, D. S. J. Am. Chem. Soc. 1951, 73, 82-87

[20]. Mukherjee, H. G.; Mandal, B.; De, S. Indian J. Chem. 1984, 23(A), 426428.

[21]. Shan, J. H.; Liu, T. Y. Acta Chim. Sinica 1994, 52, 114.

[22]. Keerti, M. N.; Sharanappa, T. N. J. Sulfur. Chem. 2011, 32(2), 123-136.

[23]. Feigl, F. Spot Tests in organic analysis, Elsevier Publishing Co., New York, NY, USA, 1956. 